\title{
ESTUDIOS
}

\section{Martí y Darío frente a Centroamérica: Perspectivas de Realidad y Ensueño}

$\mathrm{E}$ I mundo vital y artísticol de los modernistas se caracteriza por contradicciones y ambivalencias palmarias. Estas, vistas en su totalidad, son la secuela de una posición revolucionaria - personal,2 ideológica y estética- cuyas esencias de inconformidad se manifiestan de modo heterogéneo en los escritores de la época ${ }^{3}$ quienes tienen en común un anhelo de autodefinirse en un plano personal, y a la vez, universal. Pese a su rechazo de hueras instituciones sociales - burguesas y tradicionales - y en contradicción con su idiosincracia acrática, campea en sus escritos una nostalgia de normas y de orígenes, añoranza que contribuye a aumentar su estado de ánimo confuso y su desquicio espiritual. El sondeo de sus lamentaciones angustiadas y de sus apóstrofes tormentosos evidencia aquello que Octavio Paz caracteriza como una modernidad que "... no es

1 En relación a la poética rubeniana C. M. Bowra, en su pclémico ensayo Rubér Dario alude a los conflictos v a las tendencias contrarias en Darío: "Aunque los conflictos no quedan resueltos, Darío los ha dominado mediante su arte. Por lo menos en una ocasión hizo algo más que esto, unió todas sus fuerzas diferentes y antagónicas en una compleja experiencia única..." [Traducción publicada en Rubén Dario en Oxford (Managua: Academia Nicaragüense de la Lengua, 1966), p. 44.].

2 V. al respecto las sigurentes quejas de Dario en su retrato de Valero Pujol: "Para nosottos no hay sino el juicio de la mayoría impasible, seca, obesa, la burguesía que en su egoísmo o cretinismo ve nuestra consagración como un deporte cualquiera, sin advertir nuestros prematuros decaimientos, nuestros gastos de fluido vital, nuestras neurosis, ruestras tisis, nuestras dolencias cerebrales". [Rubén Darío, Obras completas (Madrid: Aguado, 1950-1953), II, 25].

3 Sobre este tema, v. por ejemplo, la brillante y esclarecedora exposición de Ricardo Gullón, "Pitagorismo y modernismo", Mundo Nuevo, enero de 1967, p. 2.2: "El modernismo, o si se prefiere, los modernistas buscaron en diferentes doctrinas defensal contra la disociación y compartimentación de la sociedad". 
sino un girar en el vacío, una máscara con la que la conciencia desesperada simultáneamente se calma y se exaspera". En su absoluto "debasamiento", como diría Martí, se descubre en los artistas modernistas una ". . búsqueda de algo y no mera disipación... [una] nostalgia de un origen". ${ }^{4}$ Si profundizamos nuestro análisis de esta literatura, hasta de su venero preciosista y exótico, descubrimos escondidas raíces indígenas, esencias nacionales y autóctonas y una geografía espiritual americana que sugieren la necesidad de escudriñar las implicaciones psicológicas 5 y noéticas de apasionadas declaraciones menospreciativas en torno a los orígenes. Tal enfoque revela una literatura que es el producto de la frustración y del abandono del artista por parte de una sociedad orientada hacia valores materialistas, racionalistas y científicos, y preocupada por los problemas creados por un proceso de transformación y modernización social y político. ${ }^{6}$ Acostumbrados como estamos a pensar tradicionalmente en el extranjerismo de la literatura modernista hemos desatendido sutiles manifestaciones americanistas - ya positivas, ya negativas- de signo psicológico, emotivo. y creador, descifrables en ellas, y hemos descuidado la necesidad de entender su función a la luz de la cosmovisión modernista.

\section{Madre Patria}

Entre los modernistas los valores criollos o autóctonos no siempre se patentizan en formas diáfanas o positivas, y rara vez a modo de una misión social como es el caso de Martí mártir y revolucionario. En algunos artistas, entre ellos Martí y Darío, motivos de hastío, irritación y rencor que pulsan bajo la superficie se concretizan en negativas expresiones en momentos de desengaño. Pero cualquiera que sea la actitud social del escritor modernista, de su concepto de la patria irradian implicaciones y sugerencias que arrojan luz sobre dos cuestiones primordiales de la ideo-

4. Cuachivivo (México: Mortiz, 1965), p. 23.

5 En nuestro estudio destacaremos la relación entre psicología y estilística, relación que Enrique Anderson-Imbert define de la siguiente manera: "El conocimiento de la realidad psicológica del escritor interesa al crítico, no sólo porque revela el sentido estético de su obra. La Estética se funda en la Psicología de la intuición y creación artísticas". [El arte de la prosa én Juan Móntalvo (México: Colegio de México, 1948), pp. 130-1311. En su dilucidación de la prosa de Montalvo, Anderson-Imbert revela cómo experiencias de resentimiento, de disgusto y de indignación moldearon la visión estética de Montalvo. El mismo proceso opera en la obra rubeniana al'usiva al tema de Centroamérica, especialmente de Nicaragua.

6 Ricardo Gullón en su Pitagorismo y modernismo resume el problema en la p. 22. V. asimismo Carlos Real de Azúa, "Ambiente espiritual del novecientos", Nimero, 2, Nos. 6-7-8 (1950), 15.36. 
logía modernista: los orígenes y la autodefinición. Y, estos temas, a su vez, como más adelante veremos, crean en el artista determinadas preocupaciones estéticas y hasta predilecciones expresivas.

La total configuración de valores noéticos y estéticos encerrados en el concepto de la patria se evidencia en la definición de Darío para quien la patria "... está contenida en la idea de individualidad, y antes de ser social, se concentra en un profundo egoísmo. La patria - continúa- es la proyección del yo en un radio de utilidad y de simpatía. Al despertar al conocimiento de las cosas y a las primeras influencias emotivas, entramos en relación inmediata con la naturaleza circundante: cielo, aire, tierra, fuentes, hierbas, hombres; todo esto que nos atrae y nos retiene, después se convierte en un símbolo; esa es la patria. Así nos amamos a nosotros mismos en el amor de la patria"? (El subrayado es mío). "Proyección del yo"; "primeras influencias emotivas"; "naturaleza circundante" constituyen un trinomio cuyos componentes psicológicos y artísticos esclarecen la posición de Darío - y en parte la de Mantí-frente a Centroamérica, y la presencia'de ella en sus obras como tema y expresión. La última sentencia, "Así nos amamos a nosotros mismos en el amor de la patria" es igualmente trascendente, pues revela cuán estrechos son los vínculos del artista con las experiencias primigenias y cuán fundamentales son éstas en el "Weltanschauung del artista maduro.

Los nexos centroamericanos de Rubén son naturales, es decir, contraidos por nacimiento en cuanto a Nicaragua, y por "utilidad", "simpatia" y experiencia de la juventud respecto a otros países de la "unión centroamericana": El Salvador, Costa Rica, Guatemala. Sus experiencias y reminiscencias centroamericanas las lega a la posteridad en poemas, crónicas y cartas que abancan la extensión de su vida; algunas veces describe la escena política, social y cultural de modo desapasionado, otras, evoca emociones, resentimientos, dolores y hasta odios. Pero, poeta en el fondo, su visión es plástica, y de la naturaleza pródiga "cielo, aire, tierra, fuentes, hierbas". La percepción dariana es, sin lugar a dudas y como nos dice Severo Sarduy, de otden plástico, ${ }^{8}$ pero recordemos que su visión de la realidad abarca contextos sociales, históricos y geográficos ${ }^{9}$ cuy a naturaleza exploraremos más adelante, comparándola con los de Martí.

El diálogo martiano con Centroamérica, aunque de signo contrario al rubeniano en sus aspectos sociales, coincide en momentos dados con

7 Obras completas (Madrid: Aguado, 1950-1953), IV, 1146. De aquí en adelante, a menos que se indique lo contratio, citaremos de esta edición utilizando una forma abreviada dentro del texto: IV, 1146.

B En "Nuestro Rubén Darío", Mundo Nuevo, enero de 1967, p. 34.

9 V. Tomás Segovia en "Nuestro Rubén Dario", p. 36. 
formulaciones noéticas y estructuras estilísticas de Dario. El nicaragüense es hijo centroamericano por nacimiento; se consideraba nicaragüense y centroamericano, identificación doble que expresó en el prospecto de $E l$ Imparcial managüense de I886: "nuestras intenciones sólo miran el bien de Nicaragua y de Centro-América".10 Maríi, en cambio, es el extranjero que abrigaba la esperanza - frustrada en breve- de que su estancia en Guatemala (1877-1878), la única prolongada en Centroamérica, pudiera ser dilatada, pues el país representaba un descanso, una "almohada" al viajero cansado ya del ajetreo impuesto por el deber.11 A Valero Pujol, amigo de Martí, y de Dario más tarde, le escribe el cubano en 1877 de un fervor patriótico mal comprendido por celosos críticos guatemaltecos; al director de El Progreso le explica su amor por Guatemala, por "... un pueblo americano, y, por tanto, mío, tan mío como aquel que el Cauto riega..."1 A continuación define la patria en un sentido lato, ecuménico y continental: "Yo naci en Cuba, y estaré en tierra de Cuba aun cuando pise los no domados llanos del Arauco. El alma de Bolívar nos alienta; el pensamiento americano me transporta" (VII, III). Martí es el errante por obligación, Darío por inclinación: "Por atavismo griego o por fenicia influencia, siempre he sentido en mí ansia de navegar", dirá Rubén. ${ }^{13}$ Martí, al contrario, anhelaba la estabilidad; deseaba echar raíces en un país libre. $Y$, en busca de él, sus andanzas lo llevaron por "Nuestra América" que consideraba su patria. Así se lo confiesa en la misma carta a Valero Pujol: ". . ¿qué falta podrá echarme en cara mi gran madre América? ¡Para ella trabajo!-De ella espero mi aplauso o mi censura" (VII, III).

El Eros patriótico de Datío es de signo subjetivo, de "utilidad y de simpatía" de visión limitada y con frecuencia ególotra; el Eros martiano

Io Citado por Diego Manue $₫$ Sequeira, Rubén Dario criollo (Buenos Aires: Kraft, 1945), p. 229.

11 En 1878 Martí comprendía que su presencia en Guatemala no iba a ser muy larga, y a Mercado le escribe de las rencillas y enemistades con que se enfrentaba: "Donde hay muchas cabezas salientes, no llama la atención una cabeza más, pero donde hay pocas que sobresalgan, vastas llanuras sin montes, una cabeza saliente es un crimen... Es una guerra de zapa en la que yo, soildado de luz, estoy vencido de antemano..." Y, agrega: "Con esto; con mi propósito de pagar aquí, esclavo de mis deudas un año, e irme; y con que Carmen cante a mi lado tan gozosamente como ahora canta, paso este año negro y respero otros años azules" [José Martí, Obras completas (Habana: Editorial Nacional, 1963-1965), $\mathrm{XX}_{2}$ 45-46]. Curioso es que antes de irse a Guatemala -en 1877-confiesa a Mercado: "preveo en mi viaje a Guatemala... un sacrificio inútil". [Ibid., $\left.\mathrm{XX}_{22} 23\right]$.

1:2 José Marti, Obras completas (Habana: Editorial Nacional, 1963-1965), VII, 110. De aquí en adelante, a menos que indiquemos otra fuente, citarenos de esta edición dentro del texto en forma abreviada: VII, 110.

13 Rubén Dario, Poesías completas (Madrid: Aguilar, 1967), p. 783. 
es un ananké de redención, de progreso, de dimensiones humanitarias y universales. Martí trabaja para América, y concebido así su destino, se eleva por encima de limitaciones y restricciones terrenas, pero sin perderlas de vista. "Madre América" es la encarnación de las aspiraciones martianas, su via crucis, un símbolo de su consagración política y social, y la razón de ser de su adolorida y atribulada existencia. Darío carece de análoga faceta redentora, fuerza motriz que salva a Martí de los desfallecimientos espirituales y las debilidades emotivas de la biografía rubeniana.

No es que Dario esquive una identificación emotiva con su patria; en $E l$ vidje a Nicaragud formula su concepto patriótico a base de la idea materna, pero ésta es distinta de la martiana: "Vivi en Chile, combatiente y práctico, que ha sabido también afianzarse en obras de paz; viví en la República Argentina, cuyos progresos asombran al mundo; tierra que fue para mí maternal y que renovaba, por su bandera blanca y azul, una nostálgica ilusión patriótica; viví en España, la patria madre; viví en Francia, la patria universal; y nada era para mí ni más orgulloso ni más grato que el nombre de un compatriota..." (III, I025). Al situarse Dario frente a Centroamérica, igual que frente a América, innegable es su capacidad para identificarse con sus problemas, desgracias y victorias. ${ }^{14}$ Pero tal identificación que a veces es visceral y otras se esfuma, nunca reviste las características martianas de dolorosa obsesión y de consagrada misión. El concepto social rubeniano, vacilante en general, sobre todo por flaquezas caracterológicas lo es aún más, en relación a Nicaragua, por motivos de encono. Estos se patentizan, por ejemplo, en las arriba citadas líneas, escritas en el momento de la euforia de su triunfal retorno a Nicaragua, en las reticencias y omisiones: Argentina es para él "maternal" y en aquella república renueva - ¿querrá decir, descubre?- "una nostálgica ilusión patriótica"; España es la "Patria madre" y Francia la universal. Nicaragua no parece merecer el epíteto materno, pues Darío reduce su mención al orgullo que siente, lejos del país, por sus hombres: ". . nada era para mí más grato que el nombre de un compatriota..." "Entre Nicaragua y Rubén -observa con tino Torres Bodet-faltó un vínculo indispensable. No el de la musa de carne $y$ hueso, de que él habló, sino el de la madre de carne y hueso: patria próxima y accesible que hace del hijo de sus entrañas un hijo de su país. Porque nada nacio-

14 De las victorias se enorgullece; tn El viaje a Nicaragua comenta: "...y cuando alguna vez, desgraciadamente, sabía el mundo de lamentables disensiones, yo no podía evitar las palpitaciones de mi corazón ante las victorias nuestras que comentaba Europa". [III, 1025]. 
naliza al ciudadano futuro como la cotidiana visión de una madre amada". 15

Además de la frustrada relación con su madre, en la memoria de Darío había más que suficientes causas - peticiones y nombramientos desatendidos- para crear en él una actitud a menudo hostil frente a Nicaragua. En el momento en que Rubén se marcha de su patria por tercera vez-en r889-observa Diego Manuel Sequeira que la tierra natal "...poco o nada había hecho por el hijo que le trajo de Chile sus más frescos laureles, y el que, ante esta letal indiferencia, proseguía su camino de eterno peregrino, musitando con amargo sabor de desilusión y desesperanza..."16 En su Autobiografía al referirse a su vuelta triunfal de I907 mezcla el júbilo de su recepción con la indiferencia del pasado: "Hacía cerca de dieciocho años que yo no había ido a mi país natal. Como para hacerme olvidar antiguas ignorancias e indiferencias, fui recibido como ningún profeta to ha sido en su'tierra..." (I, I67). En este mismo escrito relata otros momentos de desilusión y de desagradecimiento ocasionados por compatriotas. Antes de volver a Nicaragua Darío visita a Rafael Núñez, y a su interrogación "¿Piensa usted quedarse en Nicara gua?" contesta Darío, "De ninguna maneta... porque el medio no me es propicio" (I, 95). O, en otro lugar rememora con irritación datos de su Consulado de París: "El Gobierno de Nicaragua, que no se había acordado nunca de que yo existía sino cuando las fiestas colombianas, o cuando se preguntó por cable de Managua al ministro de Relaciones Exteriores argentino si era cierta la noticia que había llegado de mi muerte, me nombró cónsul en París" ( $(1,156) .17 \mathrm{Y}$, finalmente, del general Zelaya y de los obstáculos con que se encontró al querer nombrar a Rubén Ministro en Madrid, comenta en la Autobiografía en unas palabras ilustrativas de la estrecha relación entre la patria, la psicología, y el arte: "Partí, pues, de Nicaragua con la creencia de que no había de volver nunca más; pero había visto florear antiguos rosales y contemplado largamente, en las noches del trópico, las constelaciones de mi infancia" (I, I69; el subrayado es mío).

Nicaragua es para Darío una visión alejada (antiguos rosales, cons-

15 Jaime Torres Bodet, Rubén Dario; Abismo y cima (México: Fondo de Cultura Económica y la Universidad Nacional Autónoma de México, 1966), p. 21. p. 17

i6 Rubén Darío criollo en El Salvador (León, Nicaragua: Hospicio, 1965),

17 Igual queja expresa en relación al ministerio de Madrid: "A todo esto, el Gobierno de Nicaragua, preccupado con sus políticas, se accrdaba tanto de su legación en España como un calamar de una máquina de escribir... Y ahí mis apuros... No, no he de callar esto". [I, 172]. 
telaciones de mi infancia) y no motivo de angustia viva como América para Martí. En la crónica de su retorno a Nicaragua mantiene la postura del distante: "Como alejado y como extraño a vuestras disensiones políticas, no me creo ni siquiera con el derecho de nombrarlas" (III, I027). $Y$, en tono de excusa o de justificación agrega: "Yo he luchado y he vivido, no por los Gobiernos, sino por la Patria..." (III, I027-I028). El apartamiento, sin embargo, en momentos dados le produce una añoranza patriótica. En 1896 , el general 'Zelaya accede al pedido de Rubén y le escribe de Managua: "Ya que usted, a pesar de sus facilidades, tiene sólo el Diario del Saluador como medio de información de este país, haré que se lo envíen por cada correo periódicos de los que actualmente se editan aquí y que darán idea a usted del estado presente de Nicaragua". ${ }^{18}$

Dario, en relación a su patria solía obrar en términos del individuo que esperaba el debido reconocimiento, el cual necesitaba el poeta psicológicamente para satisfacer su egoísmo. En cambio, la odisea martiana revela que los rechazos, las frustraciones y hasta los viles ataques, no le arredraban ni debilitaban la consagración del apóstol al mejoramiento de América y de Guatemala. Es a Valero Pujol otra vez a quien escribe de su constancia frente a la ofensiva de sus enemigos guatemaltecos, y declara que no cejará en la faena de elevar al pueblo centroamericano: "Por ahí me han mordido unas culebras. Hasta mi talón quiero yo conservar noble. ¡Ofrenda a la gran madre!" (VII, III). Patente es que su misión terrenal, convertida en un "deber místico" - "ofrenda a la gran madre" - lo eleva y le escuda, dándole el aliento que revelan las siguientes líneas al final de la misma carta: "Vivir humilde, trabajar mucho, engrandecer a América, estudiar sus fuerzas y revelárselas, pagar a los pueblos el bien que me hacen: este es mi oficio. Nada me abatirá; nadie me lo impedira" (VII, II2; el subrayado es mio). Pero, pese a éstas y otras muchas declaraciones estoicas, en el curso de su apostolado, Martí sufre momentos de abatimiento y de desamparo, los cuales sólo revela a los amigos intimos como Manuel A. Mercado. Frente al irremediable abandono de Guatemala, Martí se desahoga con su "hermano" Mercado: ". . el premio de todo esto es que por ser cubano, y ser quien soy, me vea obligado a renunciar las pocas cátedras que me quedaban; a irme del país, y a hacerles sentir mi desdén antes que ellos me hicieran sentir su injusticia" $(\mathrm{XX}, 47)$.

18 Este deseo de saber noticias se presta a interpretaciones oportunistas, pues en la misma carta contesta el general Zelaya al of recimiento de Darío de "servir al país", lo cual Zelaya promete tener presente. [Alberto Ghiraldo, El arcbivo de Rubén Dario (Buenos Aires: Losada, 1945), pp. 158-159]. 
Lo mismo que en Martí alternan las expresiones desengañadas con las optimistas, en Darío no todo es de signo negativo en sus relaciones con Nicaragua a pesar de la maternidad frustrada. En los versos de "Retorno"19 canta al "Pueblo vibrante, fuerte, apasionado, altivo; / pueblo que tiene la conciencia de ser vivo / ... que puede bravamente presentar en su diestra / el acero de guerra o el olivo de paz". Los momentos de conciliación con el país son los de la vuelta - I907- cuando satisface Rubén su "nostalgia de\ Trópico",20 compensando asi sentimientos pretéritos de ingratitud y desaire. La posición rubeniana frente a su patria es compleja desde el ángulo psicológico pues en su ánimo y espíritu se produce un antagonismo perenne, una lid de inclinaciones contrarias. La patria, y por extensión América, en momentos dados se asocia a un sentimiento de insuficiencia ya personal, ya cultural. $Y$, a pesar de su clamor "... yo detesto la vida y el tiempo en que me tocó nacer..." en su obra aparecen manifestaciones americanistas y aún indigenistas como la del proemio de Prosas profanas: "(Si hay poesía en nuestra América, ella está en las cosas viejas: en Palenke y Utatlán, en el mito legendario y el inca sensual y fino, y en el gran Moctezuma de la silla de oro)".21 Dario, el artista exquisito y exótico descubre en el pasado indígena los valores estéticos que lo emocionan. Pero no es sólo la perspectiva pretérita de una geografía espiritual que caracteriza su visión; le preocupa y le deprime la situación del hombre moderno frente all mundo trastornado "el mundo [que] anda muy mal", "la sociedad [que] se desquicia". ${ }^{22}$

Darío es el solitario angustiado; Martí el agónico comprometido. Martí es capaz de sentirse en Cuba, como ya hemos observado, "aun cuando pise los no domados llanos del Arauco"; para él no es la tierruca lo más importante sino el ideal de la libertad. Por eso, en el momento de volver a Cuba, aprovechando la paz del Zanjón, y persuadido en su acción por su esposa, a regañadientes acepta ir poque de antemano se da cuenta de que no podrá "... dar rienda a todos estos sentimientos naturales, en "mí tan dominantes y tan vivos", ni "vivir con todas estas águilas encerradas en el corazón" (XX, 53). Tan renuente es a la idea de regresar a Cuba que le escribe las siguientes líneas imbuidas de rectitud moral a Manuel A. Mercado; testimonio son de su indefectible consagración a la

I9 Poesias completas, ed. cit., p. 783.

20 En El viaje a Nicaragua observa: "Tras quince años de ausencia, deseaba yo volver a mi tierra natal. Había en mí algo como una nostalgia del Trópico". [III, 1019].

21 Poesias completas, ed. cit., p. 546.

22. Estas palabras de Rubén proceden de "Por qué" en Rubén Dario en Costa Rica (San José: Sarmiento, 1920), II, 83. 
América libre y de su repudio de conceptos patrióticos tradicionales: “ $i$ Creen que vuelvo a mi patria! ¡Mi patria está en tanta fosa abierta, en tanta gloria acabada, en tanto honor perdido y vendido!... Voy a una tierra extraña, donde no me conocen..." (XX, 53; el subrayado es mío). Martí presiente que sufrirá la soledad del redentor: "Todo el que lleva luz se queda solo" (XVI, I6I). Darío, en cambio, experimenta la soledad del individuo frente a su destino, conftontado por el olvido y la indiferencia de compatriotas, amén de las desazones de la existencia. Martí siente y sufre las mismas ansias existenciales, peto, en vista de que el resorte vital martiano se sustrae a las pequeñeces humanas, a diferencia de Rubén, el modernista cubano es capaz de resistir las decepciones de la vida y conservar sus energías para las causas nobles y las acciones humanitarias.

\section{Nostalgia Tropical}

La nostalgia de origenes, el deseo de echar y cultivar taíces se manifiesta en ambos modernistas; Darío en términos de una visión ensoñada de su patria o de Centroamérica, Martí en los de Cuba libre y de una América adelantada y robustecida. En ambos, la abundancia tropical se traduce en emoción estética y constituye un gozo anhelado. Perenne es la presencia tropical en Darío quien según su propia confesión de 1907 , en Roma, París, Madrid o Palma de Mallorca ha oído el "...sonar de viejas campanas de nuestra catedral; por la iniciación de flores extrañas, un renacer de aquellos días purísimos en que se formaba alfombras de pétalos y de perfumes en la espera de un señor del triunfo, que siempre venía, como en la Biblia, en su borrica amable y precedido de verdes palmas" (III, I027). Remembranzas son éstas que se manifiestan anteriormente, según confesión del bardo, en versos inspirados por la naturaleza pródiga de su patria:

Agua de un vario verde y de un gris tan cambiante que discernir no deja su ópalo y su diamante,

a la vasta llama tropical.

Momotombo se alzaba lírico y soberano, Yo tenia quince años: juna estrella en la mano!

$Y$ era en mi Nicaragua natal. 
¡Oh Momotombo ronco y sonoro! Te amo porque a tu evocación vienen a mí otra vez, obedeciendo a un íntimo reclamo, perfumes de mi infancia, brisas de mi niñez. ${ }^{23}$

(El subrayo es mío).

El paisaje patrio y la identificación psicológica y estética con él comprueba cuán imprescindible es la revaloración del venero extranjerista y exótico de la literatura modernista, pues, es evidente que el llamado escapismo rubeniano tiene una faz de Jano: encubre deseos y anhelos del alienado artista rodeado de incomprensión y cuyas frustraciones se canalizan en formas expresivas que son de doble, y a veces, antagónico alcance. Esta es la antinomia que Darío observa y comenta en relación a los nexos psicológicos de otros artistas con la patria y su cultura, definiendo en el proceso la naturaleza de su propio conflicto personal:

Revolviendo nombres y categorías puede observarse: Tourguenieff estuvo siempre en la estepa; Heine, en el Walhalla; Wolf y Max Nordau, en el ghetto; Eusebio Blasco, en Fornos; Moreas, en la Morea; la señorita Vacaresco, en Rumania; Cantilo y Daireaux, en la Argentina; Marinetti, en Milán; Bonafoux, en España... (I, $465)$.

Esta reflexiones sobre la patria y la cultura originales de los desarraigados más la siguiente confesión sobre el elemento parisiense de su propia obra, constituyen un melancólico y sincero comentario en torno al tema de los orígenes y la autenticidad cultural:

Yo he sido más apasionado y he escrito cosas más "parisienses" antes de venir a París que durante el tiempo que he permanecido en París. Y jamás pude encontrarme sino extranjero entre esas gen-

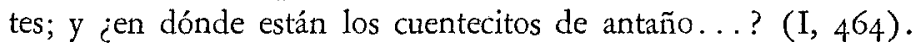

El que se siente aislado y extranjero pese a su cultura parisiense y su jactado galicismo mental24 es el Tourguenieff, el Heine de Centroamérica.

23 Poesias completas, ed. cit., pp. 705-706.

24 Sobre el tema parisiense y su relación con Centroamérica, v. también la carta a Unamuno, fechada el 9 de octubre de 1907: "Estoy al partir, de un momento a otro, para Nicaragua. Creo que el viaje, un viaje de tres meses, me harát

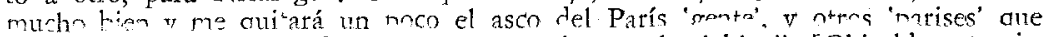
hay en este París encantador. El terruño, repito, me hará bien". [Ghiraldo, op. cit., pp. 54.55]. 
Tal es el asedio centroamericano de su ánimo que en r907 al evocar escenas juveniles conservadas de modo subconsciente, las exterioriza en un lenguaje imbuido de tropicalismo (palmas, flores, sol, oro, fuego), y en estructuras anafóricas y sintagmas no progresivos:

Saludé a Chinandega, famosa por sus naranjas, por su fecundidad agricola; saludé a León, la ciudad episcopal y escolar donde transcurrieron mis primeros años. Saludé a Managua, asiento del Gobierno; a Masaya, florida y artística! ;Viajes de palmas y flores! En mi recuerdo esturán siempre llenos de sol y de alegria. En esas horas de oro y fuego nunca pensé, como el terrible amigo pesimista, que no lejos de los domingos de ramos están los viernes santos. (III, I023; el subrayado es mío).

Idéntica visión florida se revela a los extasiados ojos de Martí, feliz, a diferencia de Darío, no de volver a patrios lares, sino de estar en el trópico, de admirar la belleza natural americana, y de poder pagarle al gobierno guatemalteco el acogimiento del exilado que todavía no ha sufrido los engaños de los envidiosos del país. En los apuntes de su viaje por Guatemala nos ofrece las siguientes pulsaciones rapsódicas de filiación tropical (cortinaje de vendura, aves blancas, pajarillos de colores) y concretadas, como la arriba citada salutación rubeniana, en estructuras anafóricas:

Traía yo el espíritu celoso de la actividad de los caribes; traía el alma tobusta con el magnífico espectáculo que a ambos lados ostentan las majestuosas orillas de un gtan río; como alas se habían pegado a mi alma aquellos cortinajes de verdura, prendidos en el cielo, mal sujetos sobre las ondas del Río Dulce, salpicados los movibles pliegues por aves blancas y pajarillos de colores. ${ }^{25}$

(XIX, 45; el subrayado es mío).

De índole menos subjetiva pero de similar disposición anafórica y enumerativa, es la siguiente descripción entresacada de Guatemala; en ella "alegran los ojos" del viajero las deslumbrantes y gratas riquezas tropicales:

25 Martí no aguantai las escenas áridas; irritan su deseo de abundancia y su sentido estético tropical: "...es bien que pasemos de prisa por estos arenales infernales, donde se busca en vano en los arroyos secos agua, color en. la quemada verba, hoias en nl mitidn árbol. Sombras largas y pardas, invariablemente blancas y negras..." [XIX, 57]. 
Aquí, sabino pálido; allí, maíz robusto, caña blanca y morada, trigo grueso y sabroso, nopales moribundos, hule nativo, ricos frijolares en asombrosa mezcla unidos, con rapidez lujuriosa producidos, esmaltan los campos, alegran los ojos y auguran los destinos de la tierra feliz de donde, vengo (VII II8).

Como Martí, Darío revela su júbilo frente a las escenas naturales del trópico, expresando su euforia en construcciones iterativas y acumulativas similares a las martianas. La estructura geométrica y enumerativa de las siguientes frases le permite a Rubén prolongar su contemplación de la belleza tropical:

$N i$ el Masaya $n i$ el Ometepec, que en la isla de su nombre es el señor del gran lago; $n i$ el Mombacho, que cercano a Granada proyecta su sombra gigantesca; $n i$ el Cosegüina, famoso en toda obra geológica de alguna importancia por su célebre última erupción; $n i$ el Felica, que hace tiempo no dice este cráter es mío; ni el Viejo, que a las veces, cuando rezonga, pone en cuidado a los chinandegueses, ninguno puede competir con el decano en cuestión. ${ }^{26}$

(El subrayado es mío).

\section{Formas Tropicales}

La memoria simbólica de Darío y Martí, admirados y emocionados ambos ante la naturaleza tropical transmuta la imagen tropical primitiva en estructuración imaginística subjetiva. De Martí es la observación reveladora de dos etapas creadoras - la mimética y la tropológica- en el camino de realidad a ensueño, de sensación a analogía: ". . nosotros hemos padecido de hojosidad, como nuestros bosques" (VIII, I9). Este es el "padecimiento" que caracteriza las impresiones plásticas de Martí tituladas "L'Amérique Centrale":

Campanarios puntiagudos: -eso es lo primero que impresiona ha vista del forastero... Se ve una gran ciudad blanca, majestuosa, soberbia. Envueltos en la niebla, los campanarios, irguiéndose por doquiera, se asemejan a los grandes mástiles de un puñado

26 "La erupción del Momotombo" en Obras desconocidas de Rubén Dario, ed. Raúl Silva Castro (Santiago de Chile: Prensas de la Universidad de Chile, 1,934), p. 6 . 
de navíos, clavados en la tierra... Grupos de árboles brillan entre las blancas casas, como esmeraldas entre ópalos. (XIX, 78).

Las esmeraldas, los ópalos y la blancura constituyen formas miméticas, plásticas e impresionistas que en otros escritos y contextos se plasmarán en bisemias, imágenes y símbolos, los cuales en Martí y Darío constituyen el ". . aposento geográfico, dentro del orden de su hogar físico..."27 La geografía real o espiritual, estética en el fondo, crea en ambos artistas un tropicalismo que se evidencia no sólo en la abundancia expresiva (i.e. frases de tendencia oratoria, acumulaciones sintágmicas) sino en ". . la lengua espejeadora de imágenes, su desatado lujo metafórico".28 Este lujo tan arraigado en la expresión de Darío como en la de Martí (pese a la engañosa sobriedad y sencillez de la expresión del cubano) lo asocia Torres Bodet con un estilo ingénito del artista hispanoamericano: "Al trasladarse a la Nueva España, el arte ibérico se encendió en oros, púrpuras, esmaltes, vidrios y espejos que, con semejante abundancia, no advertimos en los retablos de las iglesias peninsulares". ${ }^{29}$ Recordemos, a este respecto la observación de Carpentier que "nues'ro arte siempre fue barroco", aseveración que desarrolla el novelista cubano al señalar la esencia "cosificada" del barroquismo hispanoamericano, arte ". . nacido de árboles, de leños, de retablos y altares, de tallas decadentes y retratos caligráficos, y hasta neoclasicismos tardíos..."30 Teniendo en cuenta este pensamiento de Carpentier, volvamos a la ya citada definición rubeniana de la patria y veremos el circuito complejo de patria, geografía espiritual, imagen, y estructura: "...cielo, aire, tierra, fuentes, hierbas, hombres; todo esto que nos atrae y nos retiene, después se convierte en un símbolo; esa es la patria".

\section{Estructura: ABUNDANCIA y Tropicalismo}

"La literatura de casi todas las épocas -observa Dámaso Alonsoha sentido especial inclinación hacia la expresión de plutalidades..."31

27 Estas palabras pertenecen al ensayo de Gabriela Mistral, "La lengua de Martí" y sólo se refieren al tropicalismo del cubano en su contexto ouiginal donde la poetisa chilena alude a la "conjunción... de abundancia que le regaló el Trópico" a Martí. [En Antología crítica de José Martí, ed. Manuel Pedro González (México: Cultura; 1960), p. 33].

28 Loc. cit. Otra vez, Gabriela Mistral se refiere a estas manifestaciones sólo en el estilo martiano.

29 Op. cit., p. 130.

30 Alejo Carpentier, Tientos y diferencias (México: Universidad Nacional Autónoma de México, 1964), pp. 42-43.

31 Seis calas en la expresión literaria española (con Carlos Bousoño), (Madrid: Gredos, 1951), p. 13 . 
En la obra de Martí esta es una inclinación particularmente notable, diríase un rasgo constante de su expresión. Pero, en él la organización pluralística de la frase no responde a una preocupación decorativa, o a un afán preciosista y superficial, sino más bien a un imperativo estilístico impuesto por el deseo de exteriorizar de modo polifacético pensamientos y emociones complejos. "Marti adereza su lengua pero no juega con ella", observa Enrique Anderson Imbert a propósito de Amistad funesta, ${ }^{32}$ aseveración válida en relación a la obra y expresión martianas en general. En la prosa rubeniana en cambio, las construcciones pluralísticas de tendencia oratoria no aparecen con la misma insistencia que en la obra de Martí. De hecho, Darío suele concretizar su visión plástica en sintagmas cortos. "En días en que la frase española se desplegaba como un gran manto de corte, tachonada de cruces declamatorios en los discursos de Castelar... Darío escoge la frase estricta..."33 Pese a su predilección por la frase corta y "nerviosa", Dario como el cubano, sabía, y, en momentos dados se sentía impulsado a plasmar su inspiración en estructuras plurales y concatenadas que diríanse clásicas y martianas a la vez. En las siguientes líneas alusivas al doctor Castro, Darío despliega el venero pluralista de su prosa:

Como en el último sacrificio fúnebre de la llíada, en que la hoguera pagana consumió ell cuerpo del héroe; como cuando se alzaba la columna o el monumento conmemorativo sobre la tierra, o se labraba el pétreo y misterioso hipogeo debajo de la tierra, para el hombre pensador y magnánimo, para el rey fuerte o bondadoso; como discípulos que vemos expirar al maestro, que acaba de apurar, bajo el palio de la vejez, la última gota de la cicuta amarga de la vida; como marineros que quedamos, en la orilla, viendo hundirse en el mar de la sombra al esforzado capitán anciano; asi estamos nosotros, asi estamos los hijos de la patria y de la Libertad al contemplar el ocaso de este sol que se apaga.

$$
\text { (IV, I099; el subrayado es mío) }{ }^{34}
$$

32 "La prosa poética de José Martí; a propósito de Amistad funesta", en Memoria del Congreso de Escritores Martianos (Habana, 1953), p. 599. De sus construcciones barrocas agrega: "En Amistad funesta hay una variada colección de esta clase de períodos con tendencia oratoria. Sin embargo, allí no se acusan

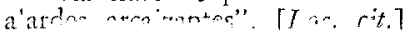

33 Torres Bocet, op. cit., p. 53.

34 En su estudio "I, Iniciación de Rubén Darío en el culto a Martí; II, Resonancias de la prosa martiana en la de Darío" Manuel Pedto González fija el comenzo de la influencia martian? en Dario on 1886. $n$ sea a principin de su estadia chilena. En particular, señala un escrito rubeniano fechado el 26 de julio del mismo año y titulado "Don Hermógenes de Irisarri" donde leemos 
Igual procedimiento constructivo, pero con mayor soltura rítmica, se evidencia en el siguiente párrafo martiano de Guatemala:

Conmovida en lo político por aquella herencia funestísima que envilece a Bolivia, que sofoca a Quito, que con ondas de sangre acaba de aumentar las poéticas ondas del río Cauca; a par solicitada por el viejo régimen que cierra las puertas a toda grande idea, atrevido proyecto o comercial mejora, y por el inexperto nuevo régimen que a toda idea útil las abre con amor, y lo trueca en depósito de frutos - cuna de riqueza- del poderoso aguardiente, del delec. tísimo tabaco; arranca su huerta, mansión antigua de opulentas coles, a la iglesia de la Recolección, y la convierte en escuela poldtécnica, mansion ahora de inteligencias ricas y vivaces. (VII, r2o; el subrayado es mío).

El polo estructural opuesto, o sea la exteriorización de la visión artística en sintagmas cortos, se evidencia con frecuencia en ambos artistas quienes en las formas expresivas de contraste revelan su voluntad de estilo y su preocupación por la renovación de la prosa. Del doctor Castro observó Darío: "Regresó. Lleno de grandes prestigios, cubierto de vida y gloria, volvió a elegirle presidente el pueblo" (IV, I IOI). Con igual precisión y sentido del ritmo de la prosa se expresará Martí en un artículo sobre Honduras: "Se observa en el cuaderno esa seguridad que atrae y

sintagmas ordenados anafóricamente y encadenados como en la cita que acabamos de presentar. Reducida la estructura estilística un esquema, se lee en uno de los párrafos del mismo escrito: "Quien con la cartera...quién en prosaicas oficinas... quién en las arduas tareas... quién, por último rompe..." Y, en otro párrafo: "en el cano vellón.... en ese brillo...", enumeración seguida de unas pluralidades asindéticas de titmo acelerado: "penacho de humo... sonoro silbido... movimiento en el parque... chispa en el yunque y fuego en el corazón... [Memoria de escritores martianos, pp. 541-543]. Difícil es precisar el momento en que Martí y su obra deslumbran a Darío por primera vez. Charles D. Watland cree que Dario empieza a leer a Martí cuando todavia está en Centroamérica el poeta niño [y así lo declara en cartá a quien esto escribe, fiechada el 28 de septiembre de 1967: "There is surely no room for doubt that Daría read Marti's articles in La Nactón while he was in Chile. But hadn't he read him befcre? I decided that he had and neither Raúl Silva Castro nor Pedro Salinas objected at all to my saying that."] En el articulo "La literatura en Centroamérica" [Obras desconocidas de Rubén Dario, pp. 201-20.2] Datio dice que "Martí alcanzó a escribir en El Porvenir de Guatemala algunos artículos, y después partió". Y, agrega: "Recordamos que el salvadoreño Francisco Castañeda... nos decía que Martí en Guatemala 'no había gustado, y con razón' ". Pero, si Darío conocía la obra martiana antes de 1886 no parece haber sufrido su ascendiente antes de este año, influencia que reputamos trascendente, pese a la afirmacićn contraria de Antonio Oliver Belmás: ". . la influencia de Martí es primeriza y pasajera en R. D." [Poesías completas, ed. cit., p. 1243]. 
doma. No lisonjea: expone" (VIII, 29). Y, en Guatemala gradúa las frases haciéndolas cortas al principio y largas - polisindéticas-al final:

La mujer es persona. El menor es persona. La tutela no es una granjería. El juicio es rápido. Las penas son más dignas. Los heredamientos serán claros. La que puede ser madre puede ser testigo. Las excepciones castellanas no aprovechan a los habitantes guatemaltecos. A vida propia, derecho, en lo necesario, propio. Tales motivos guiaron y tales efectos consigue el Código Civil, con natural regocijo promulgado entre el amor de los abogados jóvenes y el poeta agradecido, y la resistencia de los letrados de antaño, prendados de las sutilezas del "Sancho Llama" y la oscura profundidad del érudito Pérez. (VII, I49).

La creación artística en la prosa martiana se evidencia en Guatemala con insistencia alucinadora. Martí estructura las frases en esta obra con un virtuosismo arquitectónico y musical. En el siguiente ejemplo la prisa y la vitalidad de Pochuta se traducen en la encarnación estilística de la segunda frase cuya acumulación verbal-de infinitivos- refleja el proceso dinámico del pueblo: "Por Pochuta crecen muy tápidamente las haciendas. Porque es ir, plantar, esperar y hacerse tico" (VII, I33-r34). O, en otros pasajes se crea el ritmo a base de unidades bipartitas: "Cuandoi mira, / piensa. Cuando deja de hablar, / habla consigo mismo" (VII', I23.); " . . . severa, / no entristece; desdeñosa, / no irrita; bulliciosa, / no desordenada; agitada, / no cansa. Su vestido de baile nunca se aja" (VII, I24).

En cambio en El viaje a Nicaragua las manifestaciones son escasas de una voluntad de estilo, ya de indole tropical, ya escueta, similar a la que revela el ritmo de los arriba citados trozos de Guatemala.

\section{IMAgingría Y Visión PLÁSTICAS}

El trópico asedia a ambos artistas igualmente sensibles al lujo natural. Nos recuerda Torres Bodet que "el trópico fue una de las tentaciones líricas del poeta [Darío]. Verlo, entenderlo, contarlo y, sobre todo, cantarlo, le parecían deberes de su destino. Centroamericano por nacimiento, habría querido escribir El libro del 'Trópico'. ${ }^{35} \mathrm{El}$ tropicalismo fue lo que

35 Op. cit., p. 67. En su "Bibliografía de sombras en Dario", Poesias completas, ed. cit. A. Méndez Plancarte nombra este libro entre los que Darío pensaba escribit. 
Darío admiró en Martí (oro, rosas, llamarada) al exaltar el vigor y el apasionamiento del cubano en la primera mención que de Martí encontramos en su obra: "Hoy ese hombre [Martí] es famoso, triunfa, esplende, porque escribe, a nuestro modo de juzgar, más brillantemente que ninguno de España o de América. . porque cada frase suya si no es do hierro, es de oro, o huele a rosas, o es llamarada..."36 Ambos poetasi, Martí y Darío, en la concretización de su visión poética se sirven de similar o idéntica imaginería-flor, oro, rosa, sol-amén de otros tropos de signo apasionado. En contextos de tema centroamericano hay una coincidencia de perspectiva y de plasmación como la que se evidencia en los dos trozos siguientes, el primero de Martí y el segundo de Rubén.

Como en andas de flores se levanta, colgada de granadillas e bipomeas, la tierra de esmeralda y plumas donde, al espejo de sus lagos y al incensario de sus volcanes, crecen en el combate y en la fatiga, según lo manda la naturaleza, las cinco repúblicas de Centroamérica, como un solo lugar (VIII, II3; el subrayado es mío).

El paisaje de Martí es una amalgama imaginada, un mosaico impresionista. Darío evoca una escena anímica y concreta a la cual agrega un comentario de filiación moral que no es constante de su propio estilo sino del martiano, uniendo así elementos objetivos y subjetivos:

La ciudad se levantó con su traje de fiesta; las gentes se echaron a la calle; las damas lindas estaban en las puertas, rosadas al fulgor del sal; y el cielo estaba claro y el tiempo benigno, porque así quiere Dios que la naturaleza contribuya con su esplendor,

35 Obras desconocidas de Rubén Dario, p. 201. La imagen de Martí acompaña a Darío en este período. En 1889 en El Imparcial publica Darío una semblanza de Eduardo Poirier en la cual, al aludir a las traducciones hechas por Poirier afirma que una de ellas es superior a la de Martí: "Hay una edición especial de Recobrada [Called Back por Hugh Conway, traducida por Martí con el título Misterio...] cuya traducción se considera superior a la de Marti" (Rubén Dario criollo en El Salvador, p. 86). En el mismo año, en una crónica firmada "Darius" y titulada "La vida en San Salvador, Colegio de Santa Teresa" recomienda Rubén: "Que se les haga correr [a los qiiños salvadoreños] y brincar y hacer ejercicios calistécnicos, para que sean fuertes y sus cuerpos se amacicen; que se les haga leer periódicos como el que publica José Martí, 'el hombre de la Edad de Oro'..." [Ibid., p. 276]. Darío debía conocer bastante bien la obra martiana, pues en el peródico que él mismo dirigía entre 1889 y 1890 - La Unión- recibían, según Sequeira ". . . en directa colaboración desde New-York y París... las 'Cartas Americanas', de José Martí que al parecer, se publicaban simultáneamente en 'IA NACION', de Buenos Aires que contaba a Martí entre sus más ilustres collaboradores". [Ibid., p. 321]. 
tranquilidad y galas mejores a la magnificencia de un santo día de la patria. (El subrayado es mío).$^{37}$

Martí, frente a la deslumbradora belleza tropical centroamericana no es sólo el viajero y el extranjero, sino el estudioso de las costumbres nacionales. Por consiguiente, a diferencia de Darío, no deja su imaginación vagar libremente, pues escribe con un propósito social; su vuelo artístico va uncido al deseo de enseñar y de crear en sus lectores la admiración que siente él por Guatemalia. Y, al revelar al país elabora un inventario de objetos y de escenas percibidos y sentidos (oigamos, comamos, gocemos, etc.) por el cronista-artista:

Veamos cómo corren flotantes islas de mangos por el río; crucémoslo valerosamente; pongamos a una viajera enamorada, en el lindo sombrero, las florecillas rojas que acabamos de coger en el camino; oigamos, en la iglesia de Zacapa el tamboril y la chirimía, con que llaman al culto y hacen fiestas; comamos de su queso; gocemos de los chistes de su gente; anotemos en nuestra cartera de viaje la vivacidad de sus mujeres; lamentemos sus grandes tiendas, repletas antes, hoy desiertas; saludemos su iglesia y su plaza y preguntemos a este buen arriero qué le ha parecido la próspera Cobán. (VII, I30).

A pesar de ciertas discrepancias de propósito y de perspectiva entre Darío y Martí frente a Centroamérica, ambos encarnan su admiración ante la naturaleza tropical en formas plásticas, prestando a su descripción el carácter de un cuadro ya por la ingénita plasticidad de la materia, ya por las formas impresionistas que utilizan en su descripción. Dario pinta el siguiente "cuadro" de un paisaje salvadoreño:

He aquí el cuadro que luego apareció a mi vista. Sobre dos colinas juntas que traían a la imaginación una esíupenda hora calipigia, y en las cuales armonizaba en la luz toda una sinfonía en verde, la gama decreciente, el cardenillo, el verdegay, el verdinegro alimo-

37 "Una fiesta nacional" versión completa y desconocida de "Bronce al soldado Juan", publicado en la Revista Ilustrada de Nueva York, el 11 de mayo de 1891. V. por ejemplo este pasaje similar de Martí: "Más bella es la naturaleza cuando la luz del mundo crece con la de la libertad: y va como empañada y turbia, sin el sol elocuente de la tierra redimida, ni el júbilo del campo, ni la salud del aire, allí donde los hombres. al despertar cada mañana, ponen la frente al yugo, lo mismo que los bueyes. [IV, 382]. 
nado, el verde amarillo que es tierno y jocundo, resaltaban como manchas movibles unos cuantos bueyes blancos y alazanes, con el alazán boyuno y fino, que raya en metálico y resplandece en la claridad de las campiñas. ...las pequeñas agrupaciones de pasto que con su calor vivo y resaltante parecen hechas a espátula por un capricho de paisajistas. Sobre todo pasaba una ráfaga de vida, un efluvio de fecundidad; y el claror solar resplandeciente a través de las cercanas arboledas, fingía la reverberación espléndida de una decoración feérica. ${ }^{38}$

La cromología modernista cuyos matices y medias tintas (verdinegro, ver. degay, verde amarillo, etc.). Darío orquesia (sinfonía en verde, la gama decreciente) -armonizando así la plástica y la música- alterna con los contornos del cuadro, más bien sugetidos (manchas movibles) que delineados escuetamente en un todo bañado de luz. La técnica del pintor es evidente en este pasaje no sólo por la luz, el color y el procedimicnto impresionista; además de estos elementos los coordinantes verbales utilizados al final proceden del vocabulario pictórico: "parecen hechas a espátula por un capricho de paisajistas"; "fingía. . . una decoración feérica".

Igualmente impresionistas, llenos de matices cromáticos y de plasticidad son los siguientes sintagmas martianos alusivos a Sacatepéquez: "Como en fresco nidal nacientes aves, esmaltan el ameno valle de saludables corrientes y aromático clima muy numerosos y pintados pueblos. Y como descansarían las ancillas sobre brillantes hojas verdes, así los pueblos sobre tupidos valles de legumbres" (VII, I 32 )..$^{39}$

La óptica rubeniana, en su enfoque centroamericano capta líricas descripciones tropicales (e.g. tierras lujuriantes y solares):

Y allí [en una hacienda de café] gocé de espectáculos tan solamente encontrables en esas tierras lujuriantes y solares, en donde, bajo la sonora libertad del viento, en las apoteosis de los amaneceres y de los ponientes, o en las noches entoldadas de diamantes, florecen el asombro y la maravilla (III, ro3I).

Pero, al mismo tiempo, hay momentos en que Darío superpone una visión extranjera sobre la realidad centroamericana:

I3 Citado en Rubén Dario criollo en El Salvador, p. 78.

19 De Martí v. también los siguientes trozos: "Lluvia de rosas semeja el Cerro; el desorden, fruta gruesa, no altera nunca la gracia encantadora del jardin" (VII, 121); "Así, desde el Calvario domínanse las severas vías, las anchas casas, los macizos de verdura que llenan patios y escalan muros, esmeraldas entre ópalos... (VII, 122). 
Es la isla del Cardón, en Nicaragua.

Pienso en Grecia, en Morea o en Zacinto.

Pues al brillo del cielo y al cariño del agua

se alza enfrente una tropical Corinto. $4_{0}$

Estos versos nos revelan al centroamericano extranjerizado, o sea describen otra faceta del inconformismo y de la inadaptabilidad que revelara el enajenado nicaragüense de París en el texto citado anteriormente. Darío es el errante, el alienado, dentro y fuera de su país tanto como ciudadano como persona. Semejante trasposición temporal (recuérdese Palenke, Utatlán, Moctezuma de las "Palabras liminares") y espacial (como en los arriba citados versos) no es frecuente en Martí quien vive en el presente y piensa en el futuro, inspirado y alentado por la llama revolucionaria. Pero a pesar de la dimensión heroica martiana el artista modernista y el poeta en prosa - nunca ahogados por Martí-producen trozos como el que a continuación of recemos en el que el cubano se sustrae a sus circunstancias y a su momento, produciendo un cuadro histórico centroamericano repleto de detalles - de cosas-, florido y tropical:

Hoy era el mercado, de tejido y diademas, y pórfidos y oros, y birretes y tobilleras del plumón más fino, y pitos y atabales; la boda era mañana, con danzas y convites; y las casas blancas festoneadas de orquídeas olorosas; o era que el rey pasaba, con su manto de pluma azul y la corona refulgente, cargado a hombros de nobles, en su silla de oro y pedrería; o vitoreaba la multitud a los caballeros del torneo que a punta de flecha mantenian por el aire la mazorca de maíz... (VIII, II3-II4).

El pasado se funde con el instante actual al contemplar el artista la abundancia sensual circundante. En otros momentos el desplazamiento temporal se efectúa por medio de los efectos del sol que parece calcinar el ambiente y producir reverberaciones, deteniendo el tiempo y dando origen a líneas cuyas esencias solares encontramos asimismo en formulaciones rubenianas. En unas líricas evocaciones de Guatemala escribe el cubano:

Yo vengo de una tierra de volcanes altos, de feraces cerros, de anchurosos ríos, donde el oro se extiende en placer vasto por las montañas de Izábal, donde el café-forma mejor del oro-crece

40 Poesias completas, ed. cit., p. 777. 
aromoso y abundante en la ancha zona de la Costa Cuca. Allí la rubia mazotca crece a par de la dorada espiga; colosales ramos cuelgan de los altos plátanos; variadísimas frutas llenan la falda de la gentil chimalapeña; obediente la tierra responde a los benéficos golpes del arado (VII, II8).

Similar es el canto áureo de Rubén:

Dichoso el sembrador del campo que, después de sus tareas... después de derramar sudor y de crear músculos, cuando ya la espiga alegra el campo con su oro que mece el aire, tiene el aplauso del sol y la canción del pájaro, y la troje que aguarda, y el arcón que se llenará por el provecho. (II, 25)

Y a continuación agrega: "Y luego, ese maldito sol que se mete en la cabeza: bondad, generosidad, nobleza, para luego recibir la vuelta en moneda falsa".

Similares cualidades morales y abstractas atribuirá Martí al sol en su folleto Guatemala:

De indios y blancos se ha hecho un pueblo perezoso, vivaz, batallador; artístico por indio; por español terco y osado; y como el inglés es brumoso, y el sueco grave, y el napolitano apático, es el hijo de América ardiente y generoso, como el soll que lo calienta, como la naturaleza que lo cría. De manera que, de aquellos hubimos brío, tenacidad, histórica arrogancia; de los de oscura tez tenemos amor a las artes... y cuanto a tierra nueva trae una raza nueva, detenida en su estado de larva, ¡larva de águila! Ella será soberbia mariposa. (VII, II7-II8)

\section{CoINCIDENCiAs y Resonancias}

Las coincidencias de estructura y de imaginería en los escritos centroamericanos de ambos artistas son de tal naturaleza que en el caso de Darío, nos inducen a pensar en afinidades más que fortuitas. El deslinde del tema de la presencia de Martí en Darío ${ }^{4 !}$ ha revelado que el nicaragüense

41 Sobre las influencias martianas en esta etapa de la obra rubeniana, v. Manuel. Pedro González, op. cit., y nuestro estudio "Resonancias martianas en la prosa de Rubén Dario: 1898.1916" en Diez estudios sobre Rubén Dario (Santiago de Chile: Zig-Zag, 1967), 123-154. 
sentía en relación al cubano una atracción estética. De ahí que la resu. nancia de Martí cuyo retrato pintó Darío con tanto elogio en 1888 en su artículo "La literatura en Centro América", bien puede haberle sugerido a Rubén rumbos inexplorados. Sólo un artista anodado por la fascinación frente al exquisito estilo de otro escrito dedicaría un lírico panegírico, idéntica, en la expresión a las formas imaginísticas e impresionistas del que admira como se le ocurre a Darío:

...fotografía y esculpe [Martí] en la lengua, pinta o cuaja la idea, cristaliza el verbo en la letra, y su pensamiento es un relámpago y su palabra un tímpano o una lámina de plata o un estampido. A veces un titán coge una hacha gigantesca y destronca una selva. Los árboles que caen espantan el silencio solemne. Mas cuando el poeta en prosa os habla del amor, ;oh lectores!, o del arte, o de todo lo del alma que es cándido y sensible, oiréis un arpa eolia o el atrullo de un coro de palomas. ${ }^{42}$

Estas son inspiradas líneas que recuerdan la conclusión del ensayo martiano sobre Emerson (r882): "Es poesía de patriarcas, de hombres primitivos, de cíclopes. Robledales en flor semejan algunos poemas suyos... ¿No se sabe aún qué son sus versos? Son unas veces como anciano banbado, de barba serpentina, cabellera tortuosa y mirada llameante, que canta, apoyado en un vástago de encina, desde una cueva de piedra blanca, y otras veces, como ángel gigantesco de alas de oro, que se despeña desde alto monte verde en el abismo" (XIII, 30). Del mismo venero - tanto en lo estructural como en lo tropológico- es el ensayo necrológico rubeniano sobre el doctor Castro:

$\mathrm{O}$ antes, en los claustros de la Universidad leonesa, aprendiendo filosofía en latín y penetrando en el espíritu de las leyes; o cuando al retorno a su patria costarricense sirvió a Alfaro, ell halagïeño, que tenía fibra y sentimiento, que era franco y natural, sin barnices modernos, contundente como un martillo y claro como una gota de agua; o ya en mejores épocas, cuando tuvo el pensamiento amable y generoso de traer aquí a don Juan García, que levantó la enseñanza, que explicaba a los niños como un maestro moderno lo que es una rosa, lo que es una estrella.

42 Obras desconocidas de Rubén Dario, p. 201. 
Y, a continuación agrega la caracterización luminosa, símbolo clave de Martí: " Bendito el ministro bueno que para su país quería la libertad y la luz!" (IV, Iroo). En el mismo ensayo la luz se transforma en sol, sol interior, como es el martiano: "Cuando se fue a su casa llevaba las manos puras; a través de su conciencia cristalina, brillaba el sol. De oro era la medalla que llevaba en su pecho el Fundador de la Repriblica" (IV, Iror). Así dirá Martí de Daniel Webster: "De color de oro usaba el chaleco que cubría su pecho robusto; y oro, con su corazón magnánimo llevaba en su pecho" (IX, 240). Martí y Darío, por llevar "el soll dentro del cráneo" como dijo éste de Valero Pujol, en momentos no vieron "lo negro del mundo y la fortuna que se ha ido" (II, 26).

\section{Guatemala y El Viaje a Nicaragua}

El tema centroamericano en la obra de Martí y Darío se manifiesta en diversos escritos de fechas varias, pero se centra, en cuanto a la prosa, en dos, relativamente poco comentados. El de Martí, Guatemald, pertenece a 1878 , el de Rubén, El viaje a Nicaragua, a 1907. Aunque, como ya hemos visto, el móvil o impulso de los dos modernistas en la elaboración de estas obras revela significativas divergencias, con todo, existen coincidencias intrigantes aparte de las ya señaladas. En primer lugar, ambos prosistas son enamorados de la tierra que describen con lirismo. Martí deja la siguiente constancia de su amor centroamericano: "Cuando nací, la Naturaleza me dijo: jama! Y mi corazón dijo: jagradece! Y desde entonces yo amo al bueno y al malo, hago religión de la lealtad y abrazo a cuantos me hacen bien... diré con mi palabra agradecida cuánto es bella y notable, y fraternal y próspera, la tierra guatemalteca, donde el trabajo es hábito, naturaleza la virtud, tradición el cariño, azul el cielo, fértil la tierra, hermosa la mujer y bueno el hombre. Amar y agradecer" (VII, II6-xI7). En Darío el amor patrio se traduce y se manifiesta en cariñosas evocaciones de su país natal, y en rememoraciones áureas; en sus observaciones falta, sin embargo, la expresión directa del fervor patrio, carencia que sugiere reticencias y desilusiones pretéritas: " . . y y y fuese en la áspera Africa, o en la divina Nápoles, o en París ilustre, se levantó siempre de mí un pensamiento o un suspiro hacia la vieja catedral [de León], hacia mis viejos amigos; y es un hecho que casi fisiológicamente se explicaría de cómo en el fondo de mi cerebro resonaba el son de las viejas torres y se escuchaban eh acento de las antiguas palabras" (III, ro28-I029). Pero Darío no es ajeno al orgullo patrio, sobre todo en el 
momento de triunfo y de bienvenida - los de El viaje a Nicaragua-que su patria le ofrece. Reconoce que "el pais ha quedado retardado" aun en relación al progreso general de Hispanoamérica. Pero, el principio de dinamismo en un universo de valores cambiantes le acompaña y le impulsa a pronunciar palabras optimistas: "...tenemos' práctica y vitalmente demostrado que un impulso a tiempo y una aplicación de generosas y altas energías, mantenidas según las exigencias del organismo nacional, pueden, ante la revisión de valores universales, demostrar que, aparte de población o de influjo comercial, se es alguien en el mundo" (VIII, I026).

El viaje a Nicaragua es la crónica del paisaje interior del poeta, es un desfile de memorias mezcladas con la realidad circundante la que vitaliza Rubén con observaciones del presente y entusiastas comentarios sobre el futuro. El libro está dividido en secciones, once en total, en las cuales el poeta se sitúa a sí mismo respecto a su país, evoca la vida antigua de su patria, sus artes indígenas, la historia colonial, la cultura y la literatura, y más que otra cosa, la naturaleza. Esta, le fascina, revelando la trascendencia de su ya citada definición de la patria. El deleite estético del modernista se exterioriza en evocaciones en que la euforia del artista resulta en el estancamiento del tiempo: "Ia flora tropical es de una belleza que causa como una sensación de laxitud. . . he visto una tarde, en tibio crepúsculo, algo semejante a una estagnación de las horas.. . Toda la circunstante naturaleza me parecía contenida en un concentrado bloque de tiempo, atmósfera de bella-durmiente-del_bosque, o del legendario monje extasiado que escucha al pájaro paradisíaco" (III, Io33). El modernista, el amante de la belleza se rebela contra lo antiestético, y formula un pensamientofque se diría martiano: "Y calculaba al ver la feracidad de aquel terreno en que se suceden alturas y hondonadas, tupido de arbustos de riqueza, cómo es de fecundo y próvido aquel suelo y cuánto hay que aguardar de las horas futuras, cuando una apropiada y propicia corriente inmigratoria contribuya a hacer la producción más abundante y más proficua" (III, ro3.4). Darío, como Martí, desea ver prosperar a esta región tropical. Pero, a diferencia del maestro, quien silencia sus críticas y ensalza lo positivo y lo genesiaco, en Rubén los antiguos rencores y la enajenación se transparentan a pesar del goce sensual experimentado frente al paisaje nicaragüense y pese a los laureles patrios de r907. Del ambiente cultural en que se le festeja y se le honra dirá: "Hay en aquellos países [en América y en España], y en Nicaragua muy particularmente, una abundancia de materia prima, o, mejor dicho, de espítitu primo, que es de admirar. Mas el ambiente es hostil, las condiciones de existencia 
no son propicias y la mejor planta mental que comienza en un triunfo de brotes se seca al poco tiempo" (III, I059-1060). Sobre la materia prima Martí opina como Darío, pero sus conclusiones son diametralmente opuestas a las de Darío. Como revolucionario su fe en la humanidad, si no en el individuo, y su confianza en el futuro de América crearon en Martí -sobre todo en el momento de agradecimiento para con el país que lo había acogido oportunamente - una apoteosis rítmica, poética y estrófica:

Hay grandes gérmenes; descúbranse y desenvuélvanse.

Hay vastos campos; siémbrense y aprovéchense (VII, I34).

Guatemala es una obra que Martí escribe como misión: "Ni lastimar, ni poetizar, son aquí mi misión; mi misión es contar" (VII, I54). Si en el libro martiano hay una poetización de la vida y la cultura guatemaltecas ello se patentiza en las descripciones líricas, en la prosa musical, ${ }^{43}$ y en la ensoñada visión de la realidad guatemalteca que el maestro presenta. Pero, en la intimidad Martí reveló que no estaba engañado por las circunstancias. En una confesión alusiva a Guatemala hecha a Manuel A. Mercado se expresa sin rodeos: "En los países elementales, en la esfera intelectual, es muy difícil la vida de los hombres virtuosos" ( $\mathrm{XX}, 42)$; "... es verdad que yo los poetizaba ante mí mismo para poder vivir entre ellos; pero estos secretos no han salido nunca de mi alma-" (XX, 47). Estas confidencias no deben interpretarse como una apostasía ni como declaración cuyo pensamiento esté reñido con el citado anteriormente. Es que Martí tenía un sentido práctico y realista de lo que le rodeaba y si escribía con amor y optimismo es que antes se había convencido a sí mismo de la existencia de valores elogiables y había creado para sí, y en sí un mundo idealista que le permitía proferir frases como la última de Guatemald: "Ojalá que, con este amante libro, haya yo sembrado en él mi planta!" (VII, I58). Martí deseaba elevar al país, y consideraba la literatura como un magisterio social, una medida eficaz de renovación:

43 Laı voluntad de estilo de Guatemala, o sea, la evidente preocupación martiana por el ritmo de la prosa, se patentiza en muchos pasajes como el siguiente en que Martí utiliza el procedimiento de la iteración seguida, ya con una forma idéntica a la anterior, ya con una variación; remata el trozo con un sintagma brevísimo, variando así el ritmo sostenido:

Treinta $\mathrm{y}$ tres hombres comenzaron en la frontera mexicana la campaña. Vencieron, vencieron, siempre vencieron, y acrecidos, socorridos, bendecidos, los revolucionarios maravillosos entraban a ocupar el solio desierto, del heredero del autócrata. Revolución extraña, radical en resultados, fabulosa en fortuna, generosa en medios. Ni la manchó sangre inútil, ni esterelizó las sementeras. Sea loada. [VII, 123]. 
"Estudiaré . . las causas de nuestro estado mísero, los medios de renacer y de asombrar. Derribaré el cacaxte de los indios, el huacal ominoso, y pondré en sus manos el arado, y en su seno dormido la conciencia" (VII, II7). El concepto enaltecedor y la idea de revelar al mundo las potencias y las grandezas desconocidas de Guatemala campean en el escrito martiano, dimensión creadora que falta en el libro rubeniano, pero no ausente del ideario rubeniano como este trozo sobre Centroamérica revelari:

El [Barrios] bien sabe qué es lo que se le entrega: un país enfermo y agotado. Así, pues, lo primero es levantar su país. Guatemala es rica. Que se acumule esa riqueza en las arcas, y no sirva para enriquecer bolsillos privilegiados... que se vea por el ejército, que es el único, desgraciadamente, que puede devolver el prestigio perdido; que no se ataque la libertad común; que no se ofenda ningún culto; que se cuide del indio y se le redima; que se cimiente la libertad verdadera y la ley justa; que se despierte a Guatemala, en fin, después de tantos años de sueño. (IV, IIo4II05)

La ideología y el idealismo sociales encerrados en las arriba citadas líneas están en consonancia con el pensamiento martiano. De hecho, en Guatemala, dirá Martí algo similar respecto al indio: "Son resignados, inteligentes, incansables, naturalmente artistas, sin ningún esfuerzo buenos. ¡Qué gran pueblo no puede hacerse de ellos; haciendo, por ejemplo, a manera de una escuela normal de indios! ¡Un nuevo apostolado es menes. ter!..." (VII, I58).

La fuente de ambos libros es, en primer lugar, y sobre todo otro factor, la experiencia personal; partiendo de esta base subjetiva, ambos escritores agregan la historia y las lecturas literarias. Las dos obras son crónicas impresionistas, escritos esencialmente visuales, o, paisaje que en momentos dados, como ya hemos visto, se convierten en exaltaciones poéticas, producto del regodeo estético ante la naturaleza. Las formas expresivas denotadoras de la visión personal abundan en ambas obras: "Me engreía ver" (III, IO34); "divísanse" (III, ro37); "El paisaje diriase que penetra en nosotros por todos los sentidos, y hay una furia de vida que con su proximidad enerva" (III, I03.2); "El lujo del campo lo volví a admirar en las sierras" (III, I033). En un párrafo de estruc. tura barroca, anafórica y simétricamente rítmica expone Martí idéntico 
proceso visual como en los sintagmas testimoniales rubenianos arriba aducidos:

Veamos cómo corren flotantes islas de mangos por el río; crucémoslo valerosamente; pongamos a una viajera enamorada, en el lindo sombrero, las florecillas rojas que acabamos de coger en el camino; oigamos en la iglesia de Zacapa el tamboril y la chirimía, con que llaman al culto y hacen fiestas; comamos de su queso; gocemos de los chistes de su gente; anotemos en nuestra cartera de viaje la vivacidad de sus mujeres; lamentemos sus grandes tiendas, repletas antes, hoy desiertas; saludemos su iglesia y su plaza y preguntemos a este buen arriero qué le ha parecido la próspera Cobán (VII, I30; el subrayado es mío).

A este testimonio personal, agréguense los siguientes: "Ese que llaman San José es pantanoso y pobre en apariencia" (VII, I29); "¿Qué madera es ésta, tan flexible, tan blanca, tan dúctil por su cara del corte?" (VII, I38); "Allá está, airado y triste... el que antes fue próspero Izabal" (VII, I29). Estas son concretizaciones que revelan la presencia personal del artista, y a la vez, constituyen formas estilísticas que logran plasmar la plétora de visiones y de impresiones que el trópico provee al modernista. Las de Martí se exteriorizan a veces en una serie de pinceladas:

Llaman Retalhuleu a un departamento que rebosa maderas, y suculento cacao, y el exquisito grano americano.

Esto y caña produce Mazatenango, del mercantil Quetaltenango fiel tributario. (VII, I32)

Pero en otras ocasiones el artista es avasallado por la abundancia que le circunda y su visión se amplía, asumiendo proporciones kaleidoscópicas:

...el viajero asombrado, trasponiendo la entrada del Río Dulce, ve el más solemne espectáculo, la más grandiosa tarde, el más majestuoso río que pudo nunca un hombre ver. Otros más caudalosos: nuestro Amazonas. Otros más clatos: mi Almendares.

Esta es una visión mimética con términos de comparación continentales y personales. A continuación, la descripción desarrolla características estructurales y ritmicas - la iteración, la enumeración-que reflejan y sugieren la abundancia del paisaje: 
Ninguno tan severo, de tan altas montañas por ribera, de tan mansa laguna por corriente, de tan menudas hondas ondas, de tantas palomas, de tan soberbios cortinajes de verdura, del Cielo prendidos, y orlados y basados luego por la espuma azulosa de las aguas. Islas como cestos; palmas que se adelantan para abrazar; sibilíticas inscripciones en extrañas piedras; abundantísimas aves: eco sonoro, en que se escucha algo de lo eterno y lo asombroso. (VII, I29)

Darío, a diferencia de Martí, al enfrentarse con el ambiente patrio se sirve de la visión de otros para completar la suya. La vista de la flora tropical le trae a la mente, sobre todo en relación al café, el testimonio de José Dolores Gámez y su Historia de Nicaragua (III, ro34-1036). Para la historia antigua de su patria cita a Gómara (III, IO4I), y a Gámez. Darío, el memorialista que se sitúa en el presente recuerda un pasado personal, el de su juventud, $y$, a la vez, en un plano histórico, compagina la actualidad con un pasado libresco.

El pasado no está ausente del libro de Martí, pero le interesa más el momento en que escribe, pues está tratando de pintar al país de tal manera que "no se olviden los inmigrantes de la tierra que los llama, los explotadores de la fortuna que les espera, los tímidos del gobierno que les protege!" (VII, I58). Y, por consiguiente, su libro es, como él mismo lo resume, una ensoñada visión de

Anchos caminos, naturales esplendideces, bondadoso carácter, benévolo gobierno, inquietud por mejora y por riqueza; mujeres americanas y cristianas, hombres inteligentes y afectuosos, viejo arte, ansia creciente, señorial ciudad, deleitoso clima, pintorescos pueblos, seguro bienestar, fantástico crecimiento de fortuna... fertilísimo campo, California agrícola (VII, I58).

Donde coinciden Darío y Martí en la elaboración sistemática de un tema, aparte del de la naturaleza tropical, es en la discusión de los valores literarios centroamericanos. A pesar de la ya citada observación rubeniana que el ambiente nicaragüense es hostil a la fruición de la "materia prima" artística en el apartado $V$ de su Viaje... pasa revista a la literatura patria, pero, sin demostrar en ningún momento el entusiasmo de Martí que se transparenta en pártafos inspirados como el siguiente sobre José Batres: 
Sus descripciones, ora gráficas en una frase, ora ricas de vericuetos y detalles; sus pintorescas enumeraciones; la burlona amargura con que flagela el falso pudor, la necia petulancia, la monjil severidad, la vanidad ridícula; los raros, desusados y valientes giros con que matiza su lenguaje; la rica instrucción literaria que revelan sus naturales alusiones; el seductor descuido; las inagotables sales; los punzantes episodios; la filosófica sensatez; el castizo abandono de aquel ingenioso que sabía elevarse como el águila, gemir como la paloma, vivacear como la ardilla, hacen del vate guatemalteco... una extraña figura, pálida, profunda, entera, hermosa y culminante. (VII, I4I-I42)

En la revisión de los valores literarios nicaragüenses la única chispa creadora de Darío, el único instante en que su prosa se eleva por encima de lo gris y chato, se evidencia cuando discute la obra de Enrique Guzmán, cronista provinciano y gramático: “¡Excelente señor Guzmán, el mismo, invariable, incambiable desde hace treinta, cuarenta, cincuenta años, qué sé yo!" (III I063). La ironía rubeniana se convierte en evidente hastío y cólera frente a la nulidad del ambiente literario patrio en otro texto sobre Guzmán y la Nicaragua literaria (I89I):

Un amigo mío muy inteligente, dijo una vez:

En Centro América la llamada crítica, o quema incienso o escupe el rostro. La faena que en Centro América, tiene Enrique Guzmán está basada en su formidable, asombrosa, aterradora crítica! ¡Dios mío! a su lado sólo Taine, Bourget, Valera, Clarín...

En Nicaragua sobre todo; entre los trescientos habitantes de la República, hay una multitud que no discute a Guzmán. "¡Oh, Enrique... gran cosa! ¡Nadie como él!" $Y$ se les cae la baba. ¡Brutos! 4

La consanguinidad de la crítica literaria de Darío y Martí se evidencia mejor si no nos limitamos a El viaje a Nicaragua. Si en cambio utilizamos textos centroamericanos como el siguiente de 1890 donde Darío describe el arte de una figura con quien Martí también tuvo contacto - Valero Pujol- se verá paulatinamente la relación de la crítica rubeniana con la martiana:

44 Rubén Dario en Costa Rica, III, 56-57. 
Sus bravas interjecciones aragonesas de sonoro cobre español. Es apasionado como un poeta, convencido como un apóstol, audaz como un soldado. Parapetado en su convicción, bien armado de sólidos principios, se bate y avanza. A cada instante miráis el fogonazo. Defiende su ideal; pelea por su causa con el valor de un cruzado, y sobre su cabeza flamea al viento la soberbia bandera de la libertad y el progreso. ¿Retroceder un solo paso? Por nada: es de la tierra de la Pilarica, la virgen épica, donde los hombres no cejan y son firmes como si estuviesen hechos de carne de roble. Serán diez contra él, serán cien, serán mil, serán la inmensa muchedumbre enemiga: él defenderá su credo, él sonará su clarín y caminará para la victoria, porque se llama Legión. (II, 24).

En estas frases se evidencia la estructuración melódica, o mejor dicho, arquitectónica de sintagmas en formulaciones anafóricas, el uso de verbos iniciales (parapetado, armado; defiende, pelea; seran... serán... serán... serán) como en el texto arriba citado de Martí (elevarse, gemir, vivacear), y la enfática conclusión en que como martillazos se sirve Darío de "él" en posición inicial sintágmica, en cláusulas cortas de tensión limitada.

\section{COINCIDENCIAS TEMÁtTicas}

El cultivo del tema literario con similitudes temáticas o estructurales no es el único nexo del ideario de los dos artistas, como ya lo hemos indicado. Pero, la crónica artística y, en especial las características individuales que reviste en ambos modernistas constituye un modo particularmente apto para comparar el concepto y la idiosincrasia vis a vis Centroamérica y su plasmación artística. Sobre la misma poetisa centroamericana, María Josefa García Granados, escriben ambos: Darío en su "Literatura en Centro América" (1888); Martí en Guatemala. La carencia de entusiasmo con que Rubén se aproxima a su tema se refleja en su estilo carente de adorno y de ritmos. Su escasa emoción es el producto de una actitud negativa frente a la cultura centroamericana, actitud que se transparenta en la observación siguiente: "¡Oh, pero todo es escaso. No hay público, no hay lectores sino en pequeñísimo número. . "45 De ahí el tono desganado que caracteriza su retrato de la poetisa:

45 Obras desconocidas de Rubén Dario, p. 210. 
Nos referimos a María Josefa García Granados. Su apellido es uno de los más conocidos desde los ticmpos de la colonia. Sus versos son casi ignorados fuera de su país. Fue esta poetisa de carácter hombruno y talento audaz. Dicen que era gran improvisadora, y que gustaba de los asuntos libres para sus versos, que se inmiscuía en la política y que echaba letrillas y glosas por su pluma, que daban escozor a los gobernantes y encendían las mejillas de las damas que en ellas ponían los ojos. 46

En comparación, Martí compone este retrato de variados ritmos que reflejan la música interior de un poeta en prosa:

Hubo ¡también muerta! una poetisa en Guatemala, amiga de Batres, famosa decidora, que no dejó suceso sin comentario, hombre sin gracioso mote, defecto sin epigrama, conversación sin gracia. Talento penetrante, alma ardiente, rima facilísima, espíritu entusiasta, carácter batallador, fue María Josefa García Granados por mucho tiempo animación y para siempre gala de la literatura guatemalteca.

Ella no desdeñaba ir a las prensas, publicar papeles, provocar controversias, sostenerlas con brío. En prosa como en verso escribía con sólida fluidez. Era abundante, pero tanto en pensamientos como en verșos (VII, I44).

En el mismo artículo en que discute Rubén la obra de la poetisa García Granados, plantea un tema dilecto-desde los versos primigenios-y perenne de su ideario: la unión centroamericana, Darío, vislumbra la imperiosa necesidad de unir la política y el arte, sobre todo, en los países centroamericanos donde la literatura no puede prosperar, ni siquiera existir, sin el apoyo oficial. En su concepto, la unión daría mayor fuerza a las pequeñas naciones hispanoamericanas $y$, por extensión, a las letras que en ellas se cultiven:

46 Ibid., pp. 190-191. En 1891 Darío considera a Guatemala la excepción al lamentable estado cultural de América. En "Páginas de un libro inédito" observa: "En Centro América no ha habido jamás cultura intelectual. En tiempos pasados aparecen algunas cuantas personalidades en ciencias o en artes, que van a la cabeza. Han surgido sabre todo en Guatemala. $Y$ es porque ha sido siempre Guatemala, el lugar donde han ido a beber luz todos los sedientos de las cuatro restantes repúblicas". [Rubén Darío en Costa Rica, II, 53]. 
Mientras no haya unión siquiera en la vida del alma, ya que no ¡ay! en la vida política, entre las cinco pequeñas naciones en que está dividida la antigua federación centroamericana, las letras, como manifestación verdadera de la existencia de un pueblo, no pueden ser allí sino escasas, débiles, pobres. ${ }^{47}$

Sin la unión, observa, "seremos desconocidos, no digo en el otro continente" sino "en estas mismas naciones de nuestra raza".48

Martí apoya el mismo ideal de la unión, ideal que en Darío se convierte en voz militante al asumir él la dirección de La Unión, periódico salvadoreño que defiende, con el respaldo del Presidente de la República, la idea de la unión. Martí también cree en la unión: ". . cinco países cuyo parentesco será más poderoso que la pócima de ira con que les alborotó las venas el conquistador" (VIII, II3); "Esas Repúblicas... acabarán por no ser más que una sola, como las leyes de la naturaleza, de la política y de la utilidad lo ordenan..." (XIX, 94). Pero, su visión ecuménica no se detiene en la consideración de la política centroamericana. A diferencia de Darío se preocupa en todo momento por el bien de América: "Por sistema-le confiesa a Joaquín Macal-me tengo vedada la ingerencia en la política activa de los países en que vivo. Hay una gran politica universal, y esa sí es la mía y la haré: la de las nuevas doctrinas" (VII, 98). Estas son en parte las de la revolución ideológica implícita y fundamental en la renovación modernista. $Y$, como elemento constitutivo de una visión universal, dentro de una novadora concepción del mundo, Martí las relaciona con Centroamérica y el continente: "Por primera vez me parece buena una cadena para atar, dentro de un circo mismo, a todos los pueblos de mi América!" No utiliza la locución "nuestra América" como tantas otras veces, sino más bien "mi América", reveladora de un vínculo estrecho e íntimo entre el cubano y su patria universal.

El americanismo de Darío, en un plano político y moral, no demuestra ser tan profundamente enraizado como el de Martí; no reviste características de abnegación, de altruísmo, de rectitud y estoicismo frente a los que quisieran utilizar la política para fines egoístas. Pero, con todo, en Darío hay, como ya lo hemos sugerido en este estudio, una conciencia americana. En su artículo "Una opinión del Boston Herald"' se queja de

47 Ibid., p. 212.

48 Loc. cit. 
las exageraciones y errores que comete la prensa al describir los acontecimientos centroamericanos:

¡Lo mucho que tienen de bueno se calla por alguno para poner de bulto solamente sus faltas...

Por esto es que nos duele hondamente en el alma cada vez que un órgano de la Prensa extranjera, con prestigios o sin ellos, usa de la cincerrada para con los países centroamericanos (IV, II33).

Aquí tenemos otra versión de las palabras ya citadas de El viaje a Nicaragua donde Darío deja el testimonio de cómo le alegraba recibir noticias nicaragüenses de acontecimientos enorgullecedores. Pero, en lo arriba citado, como en las observaciones de su Viaje... no encontramos el dolor ni la preocupación patrios que en Martí descubrimos como regla general. De Honduras, por ejemplo, escribe el Maestro en La República (I886):

Que es país que comienza, ya se sabe; pero debía inspirar respeto la suma de sus infortunios pasados, y el impetu que se consagra a su remedio. Mal ayuda a un país el que lo presenta como una selva enmarañada, donde las mulas no tienen donde poner el pie, y las minas cuestan más de lo que dan, y no hay pan que comer. (VIII, 28).

No es sólo el "dolor hondo" rubeniano arriba expresado que orienta a Martí; es más bien el imperativo ético del revolucionario, como se echa de ver en la carta escrita en 1894 a Román Mayorga Rivas:

Me figuro que quizás empieza para nuestros pueblos ( $j$ ay, y Dios no lo quiera!) de la América indohispánica, una serie larga de sacrificios de vidas buenas y necesarias, todo por el Ideal, sin que a la postre el gran Ideal salga triunfante (VIII, 42).

La protesta martiana contra el invasor aun cuando llega con "buenas intenciones" motiva las siguientes líneas:

De tiempo atrás venía apenando a los observadores americanos la imprudente facilidad con que Honduras, por sinrazón visible más confiada en los extraños que en los propios, se abrió a la gente rubia que con la fama de progreso le iba del Norte a obtener allí, 
a todo por nada, las empresas pingües que en su tierra les escasean o se les cierran. Todo trabajador es santo y cada productor es una raíz... pero con el pretexto del trabajo, y la simpatía del americanismo, no han de venir a sentársenos sobre la tierra, sin dinero en la bolsa ni amistad en el corazón, los buscavidas y los ladrones (VIII, 36).

Lejos estamos, en lo arriba citado, de la posición deleznable de Darío, quien enfermándose en Nueva York hacia el fin de su vida acepta la invitación del dictador guatemalteco, Estrada Cabrera y viaja a su país en I9r5. Darío sufre, pero sirve a este "rey burgués" componiendo para él "Palas Athenea", 49 y en ocasión del cumpleaños de su madre, "Mater Admirabilis" (dedicado a Manuel Estrada Cabrera). Guatemala es para el enfermo y claudicante bardo el país hospitalario que lo recibe en un momento de crisis, igual que en el caso de Martí en 1877 . Pero, a diferencia de Darío, víctima irremediable de los efectos de la dipsomanía, y ya próximo a la muerte, Martí conserva su honor íntegro y no transige ni compromete su dignidad frente a las fuerzas nefastas del país. Abandona Guatemala en lugar de sacrificar sus principios, como en $\mathrm{I88}$ I ante las demandas del dictador Guzmán Blanco de Venezuela. Recordemos, sin embargo, que en días más felices Darío supo reconocer y ponerse del lado de la justicia política, revelándose superior a aquella "su lamentable flaqueza humana". 50 El segundo período salvadoreño es quizá el momento en que con mayor vigor arde en Dario el fuego del altruismo y de la moral. En párrafos introducidos por apotegmas de filiación martiana y los cuales podría haber escrito el Maestro, Darío condena la prostitución periodística en "La misión de la prensa" ( 1890 ):

La pluma es arma hermosa.

El escritor debe ser brillante soldado del derecho, el defensor y paladín de la justicia.

Son gloriosas esas grandes luchas de la prensa que dan por resultado el triunfo de una buena causa, la victoria de una alta idea. Por eso los que rebajan pensamiento y palabra en ataques desleales e injustos; los que convierten la imprenta, difundidora de luz, en máquina exaltadora de ruines pasiones; los que hacen de ese após-

49 Al final de la tetcera sección dice: "Así avanza la mensajera / de la luz por la selva fiera / de nuestra América Central.... / y saluda a Estrada Cabrera / ..." [Poesias completas, ed. cit., p. 1132].

50 Torres Bodet, op. cit., p. 321. 
tol: el periodista; un delincuente, un pasquinero... esos rebajan la noble misión del escritor; truecan el soldado en bandolero. 51

Y, en El Salvador, cuando ocurre el golpe de los Ezeta, contra la autoridad del Presidente Menéndez, Darío, en lugar de ceder a la autoridad de los nuevos, y de acudir a la llamada de Carlos Ezeta, huye a Guate: mala donde escribe su "Historia negra de los Ezeta", crónica condenatoria de la ruin acción de los Ezeta. "La verdad es - nos explica en su Autobiografia - que yo estaba satisfecho de mi conducta, pues Menéndez había sido mi benefactor y sentía repugnancia de adherirme al círculo de los traidores. ¡Será ello quizás un poco romántico y poco práctico; pero quẻ le vamos a hacer!" ( $\left.I, 7^{6}\right)$. Similarmente, en el momento de corregir las pruebas de su "Viaje a Nicaragua" le "legaron las noticias de los últimos acontecimientos que han perturbado la paz de aquella República y producido la caída del Presidente Zelaya" (III, r ro9). En el capítulo XI de dicho libro Darío explica que no piensa suprimir los elogios y sustituirlos con críticas (III, Irog).

La actitud política de Dario frente a la "tierra ardiente y fecunda" está cifrada en las siguientes palabras: "Yo he luchado y he vivido, no por los Gobiernos, sino por la Patria; y si algún ejemplo quiero dar a la juventud de esta tierra ardiente y fecunda, es el del hombre que desinteresadamente se consagró a ideas de arte..."52 (III, 1027-ro28).

Dario es ante todo artista, y por lo tanto antepone el arte y la cultura a cualquier otra consideración. De allí que no es motivo de asombro que entre las últimas líneas que escribió, en una evocación de Guatemala, encontremos la reiteración de la trascendencia y primacía de lo estético y de lo cultural. Al nombrar a Guatemala le viene a la memoria el recuerdo de artistas e intelectuales:

5l Rubén Dario criollo en El Salvador, pp. 198-199. En el mismo periódico, La Unión; publica Darío estos apotegmas de rectitud moral: "No en vano se derrama, pues, la sangre en servicio de las grandes causas, por cada gota que cae, devuelve la tierra un adalid destinado a sostenerda" (IV, 1073-1074). Martí prodiga estas sentencias morales, mientras que en Darío aparecen con relativa infrecuencia. Compárese esta observación martiana: "El que vive de la infamia, o la codea en paz es un infame. Abstenerse de ellas no basta: se ha de pelear contra ella. Ver en calma un crimen, es cometerlo" (V, 168).

52 En el mismo libro, El viaje a Nicaragua, emite otros juicios peyorativos sobre la política: "Hay que tener en cuenta que todos los escritores tienen necesariamente que ir a parar al terreno de las discusiones políticas. Los mejores cerebros se han gastado así" (III, 1062); "¿Y la política? Yo no me ocupo ahora en la política..." (III, 1082). Mucho antes --en 1886- había declarado su desprecio por los políticos: "La política es agua de pasto de todo Cristo en esta tierra. Política por la mañana y política por la tarde... ¡Demontre con la política! - iDe politicorum omnium, libera nos Dómine!' [Sequeira, Rubén Dario criollo, p. 231]. 
¡La tierra del Quetzal! Ella, entre otros, acogió a Martí, arrulló a Joaquín Palma, al ecuatoriano Proaño, al español Pujol, al polaco Leonard, almas todas que tuvieron que ver con las gentiles Piérides o con la protectora Atbenea (I, 885).

La geografia espiritual centroamericana del reino interior de Dario culmina en una ensoñada concepción del "país del sol", de "las ilusiones en flor, el trópico vibrante y cálido", como lo expresara en $A$. De Gilbert (II, I56). En "Páginas de un libro inédito" afirma: "Centro América, tierra caliente, es país de poderosas imaginaciones y grandes talentos. Eso no es herencia de España, sino fruto del sol y del continente (el subrayado es mío). ${ }^{53}$ Implícita es en estas últimas palabras la relación entre el conjunto cultural, la naturaleza, las formas expresivas y los componentes imaginísticos de su "geografía espiritual".

El encuentro centroamericano de Martí se produce y se concretiza de modo análogo a pesar de móviles y actitudes antagónicos. El nexo entre geografía y arte es consciente según nos muestra su confesión (1878) alusiva a Guatemala: "Como gusto mucho de lo ancho, de lo elevado y de lo vasto, y en nuestra América todo lo es, tal vez abunden estas palabras repetidas..." (XX, 40).

Estos dos epígonos del modernismo, motivados psicológicamente de manera distinta, reconocen así el idéntico y potente ascendiente sobre su arte de la naturaleza y la cultura; ambos, por el camino de la expresión artística se ubican culturalmente, satisfaciendo, en parte, si no del todo, la pungente "nostalgia de un origen".

Wasbington University

IVAN A. SCHULMAN

53 Rubén Dario en Costa Rica, II, 52. 